\title{
Maple pollen season in selected cities of Poland in 2018
}

\author{
Katarzyna Dąbrowska-Zapart', Kazimiera Chłopek1, Agnieszka Świdnicka-Siergiejko², Grzegorz Siergiejko³,

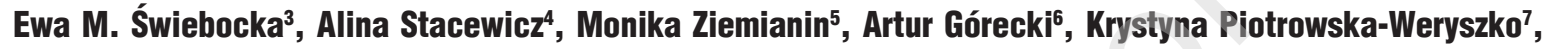 \\ Aneta Sulborska ${ }^{7}$, Dariusz Jurkiewicz ${ }^{8}$, Ewa Kalinowska ${ }^{9}$, Agnieszka Kwaśnik-Balińska ${ }^{8}$, Kornel Szczygielski ${ }^{8}$, \\ Małgorzata Puc ${ }^{4}$, Daniel Kotrych ${ }^{10}$, Agnieszka Lipiec ${ }^{11}$, Piotr Rapiejko ${ }^{8}$ \\ ${ }^{1}$ Department of Paleontology and Stratigraphy, Faculty of Earth Sciences, University of Silesia \\ ${ }^{2}$ Department of Gastroenterology and Internal Medicine, Medical University of Bialystok \\ ${ }^{3}$ Pediatrics, Gastroenterology and Allergology Department, University Children Hospital, \\ Medical University of Bialystok, Poland \\ ${ }^{4}$ Department of Botany and Nature Conservation, Faculty of Biology, University of Szczecin, Poland \\ ${ }^{5}$ Department of Clinical and Environmental Allergology, Jagiellonian University, Medical College \\ ${ }^{6}$ Institute of Botany, Jagiellonian University \\ ${ }^{7}$ Department of Botany, University of Life Sciences in Lublin, Poland \\ ${ }^{8}$ Department of Otolaryngology with Division of Cranio-Maxillo-Facial Surgery in Military Institute of Medicine, \\ Warsaw, Poland \\ ${ }^{9}$ Allergen Research Center, Poland \\ ${ }^{10}$ Department of Orthopedics and Traumatology, Pomeranian Medical University of Szczecin, Poland \\ ${ }^{11}$ Department of Prevention of Environmental Hazards and Allergology, Medical University of Warsaw, Poland
}

Abstract: The study compares the maple pollen seasons in Bialystok, Bydgoszcz, Cracow, Drawsko Pomorskie, Sosnowiec, Lublin, Olsztyn, Opole, Piotrkow Trybunalski, Szczecin, Warsaw and Zielona Gora in 2018. The investigations were conducted using the volumetric method. The maple season started in all sites in the first decade of April, with the exception of Sosnowiec, where the season began already on March $16^{\text {th }}$. The peak values of seasonal pollen count occurred between $12^{\text {in }}-20^{\text {in }}$ April in all cities. The highest daily pollen count was recorded in Sosnowiec and in Lublin on the same day (12 April) in both cities. The greatest risk of allergies caused by the presence of airborne maple pollen was observed in Sosnowiec, Lublin and Opole.

Key words: allergens, pollen concentration, maple (Acer), Poland, 2018



he Acer genus comes from the Sapindaceae family and is represented by approx. 150 species $[1,2]$ occurring mainly in the temperate climate zone. In Poland, the maples are widespread, and there are 3 native species that occur in natural environment: Acer platanoides L., Acer pseudoplatanus L. and Acer campestre [3]. They occur in deciduous forests, also near streets and in parks. One species of Acer negundo is considered an invasive species in Poland [4], which is common in almost the entire country except in Pomerania and North-Eeastern Poland. Additionally, many species are common trees and decorative shrubs, e.g. A. tataricum, A. rubrum, A. saccharinum and A. palmatum. Despite the wide spread of the Acer genus in the air, large amounts of pollen grains of this taxon are not recorded [5]. This is due to the fact that most of the maple species are entomophilous. Significant amounts of pollen present in the air most likely come from the 
Acer negundo species [6, 7]. In allergology, maple pollen does not play a vital role, because it has weak or medium sensitizing properties $[8,9]$.

Aim

The aim of the study was to compare the maple pollen season in Bialystok, Bydgoszcz, Cracow, Drawsko Pomorskie, Sosnowiec, Lublin, Olsztyn, Opole, Piotrkow Trybunalski, Szczecin, Warsaw and Zielona Gora in 2018.

\section{Material and method}

The measurements of the pollen concentration in the study sites were performed with the volumetric method using Burkard and Lanzoni pollen samplers. Microscopic observations were performed on preparations obtained in a 7-day cycle with assessment of 24-hour periods. The results were expressed as the number of pollen grains in $1 \mathrm{~m}^{3}$ of air per day $\left(\mathrm{P} / \mathrm{m}^{3}\right)$. The start of the season was defined as a date when $1 \%$ of the seasonal cumulative pollen count was trapped and the end of the season when cumulative pollen count reached $99 \%$. The total pollen count over this period was expressed by the symbol SPI (Seasonal Pollen Index). The course of the pollen seasons in each city is shown in the graphs (fig. 1-6).

\section{Results and discussion}

In 2018, the maple pollen season started between $16^{\text {th }}$ March (Sosnowiec) and 12 ${ }^{\text {th }}$ April (Bydgoszcz, Drawsko Pomorskie, Olsztyn and Szczecin) and ended at the turn of April and May (tab. 1, fig. 1-6). In Sosnowiec, compared to other cities, a very long pollen season was found, which was 54 days (tab. 1). The highest maple pollen concentrations were detected in the second decade of April (12 $12^{\text {th }}-20^{\text {th }}$ April) in all analyzed cities (tab. 1). The highest daily pollen count was recorded in Sosnowiec $-152 \mathrm{P} / \mathrm{m}^{3}$ and in Lublin $-144 \mathrm{P} / \mathrm{m}^{3}$ on the same date in both cities (12 $2^{\text {th }}$ April) (fig. 1). While the lowest concentration of pollen was found in Cracow - it was only $7 \mathrm{P} / \mathrm{m}^{3}$ (fig. 3).

Table 1. Characteristics of Acer (maple) pollen season in 2018.

\begin{tabular}{|c|c|c|c|c|c|}
\hline Site & $\begin{array}{l}\text { Duration of pollen season } \\
\text { (number and days) }\end{array}$ & $\begin{array}{c}\text { Peak value }\left[\mathrm{P} / \mathrm{m}^{3}\right] \\
\text { and peak date }\end{array}$ & $\begin{array}{l}\text { Seasonal Pollen } \\
\text { Index - SPI }\end{array}$ & $\begin{array}{l}\text { Number of days concentration } \\
\text { above threshold } 20 \mathrm{P} / \mathrm{m}^{3}\end{array}$ & $\begin{array}{c}\text { Number of days concentration } \\
\text { above threshold } 50 \mathrm{P} / \mathrm{m}^{3}\end{array}$ \\
\hline Bialystok & $\begin{array}{c}10.04-1.05 \\
22\end{array}$ & $\begin{array}{c}19 \\
17.04\end{array}$ & 84 & 0 & 0 \\
\hline Bydgoszcz & $\begin{array}{c}12.04-2.05 \\
21\end{array}$ & $\begin{array}{c}54 \\
18.04\end{array}$ & 307 & 7 & 1 \\
\hline Cracow & $\begin{array}{c}9.04-6.05 \\
28\end{array}$ & $\begin{array}{c}7 \\
15.04\end{array}$ & 23 & 0 & 0 \\
\hline $\begin{array}{l}\text { Drawsko } \\
\text { Pomorskie }\end{array}$ & $\begin{array}{c}12.04-8.05 \\
27\end{array}$ & $\begin{array}{c}27 \\
17.04\end{array}$ & 164 & 1 & 0 \\
\hline Sosnowiec & $\begin{array}{l}16.03-8.05 \\
54\end{array}$ & $\begin{array}{c}152 \\
12.04\end{array}$ & 849 & 10 & 4 \\
\hline Lublin & $\begin{array}{c}4.04-29.04 \\
26\end{array}$ & $\begin{array}{c}144 \\
12.04\end{array}$ & 701 & 10 & 3 \\
\hline Olsztyn & $\begin{array}{c}12.04-1.05 \\
21\end{array}$ & $\begin{array}{c}36 \\
20.04\end{array}$ & 205 & 4 & 0 \\
\hline Opole & $\begin{array}{c}9.04-29.04 \\
21\end{array}$ & $\begin{array}{c}121 \\
13.04\end{array}$ & 689 & 9 & 5 \\
\hline $\begin{array}{l}\text { Piotrkow } \\
\text { Trybunalski }\end{array}$ & $\begin{array}{c}9.04-25.04 \\
17\end{array}$ & $\begin{array}{c}72 \\
15.04\end{array}$ & 371 & 6 & 2 \\
\hline Szczecin & $\begin{array}{l}12.04--3.05 \\
22\end{array}$ & $\begin{array}{c}85 \\
19.04\end{array}$ & 311 & 3 & 1 \\
\hline Warsaw & $\begin{array}{c}11.04-5.05 \\
25\end{array}$ & $\begin{array}{c}84 \\
14.04\end{array}$ & 375 & 7 & 2 \\
\hline $\begin{array}{l}\text { Zielona } \\
\text { Gora }\end{array}$ & $\begin{array}{c}9.04-29.04 \\
21\end{array}$ & $\begin{array}{c}65 \\
14.04\end{array}$ & 413 & 9 & 3 \\
\hline
\end{tabular}




\section{MEDIGAL AEROBIOLOGY}

ORIGINAL PAPER

Figure 1. Maple pollen count in Lublin and Sosnowiec in 2018.

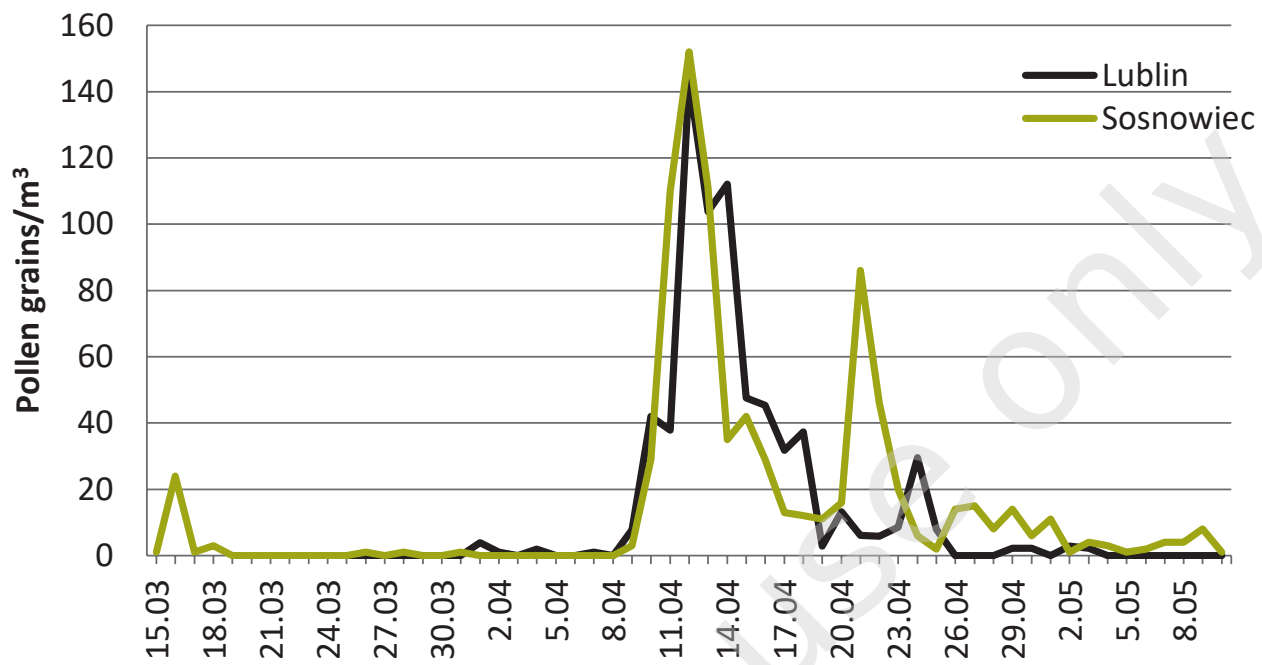

Figure 2. Maple pollen count in Olsztyn and Opole in 2018.

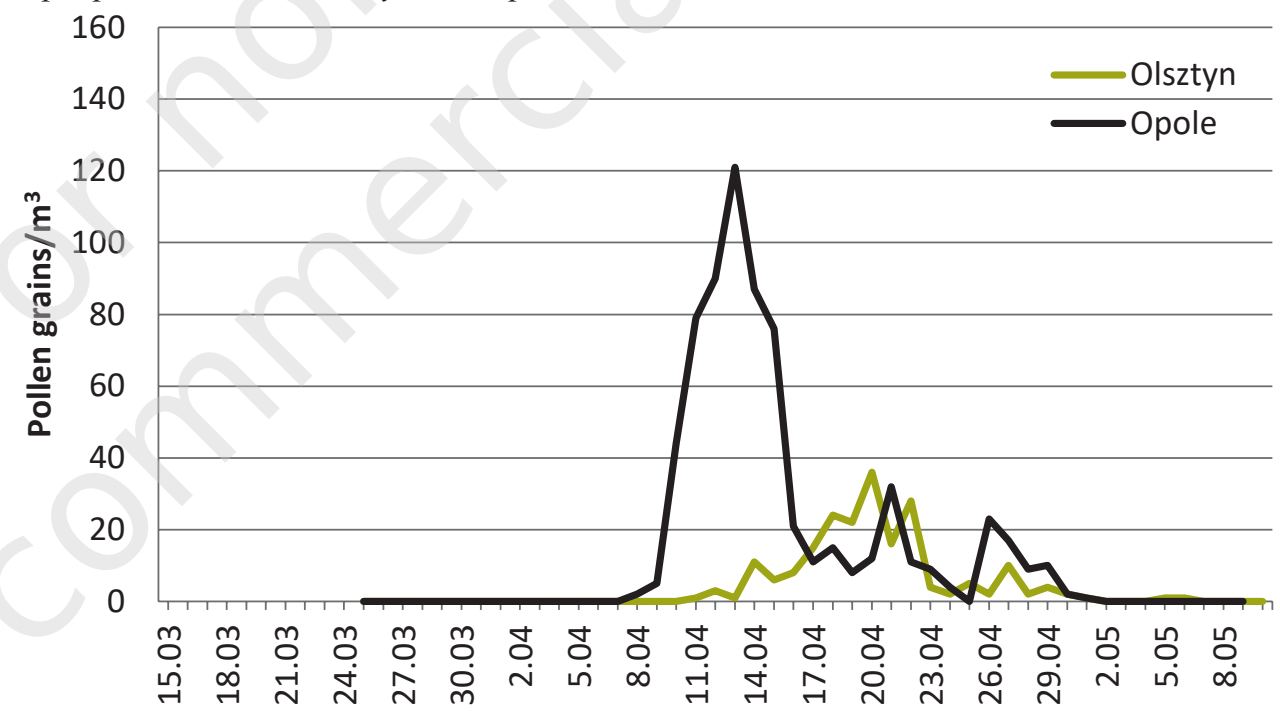

Figure 3. Maple pollen count in Cracow and Drawsko Pomorskie in 2018.

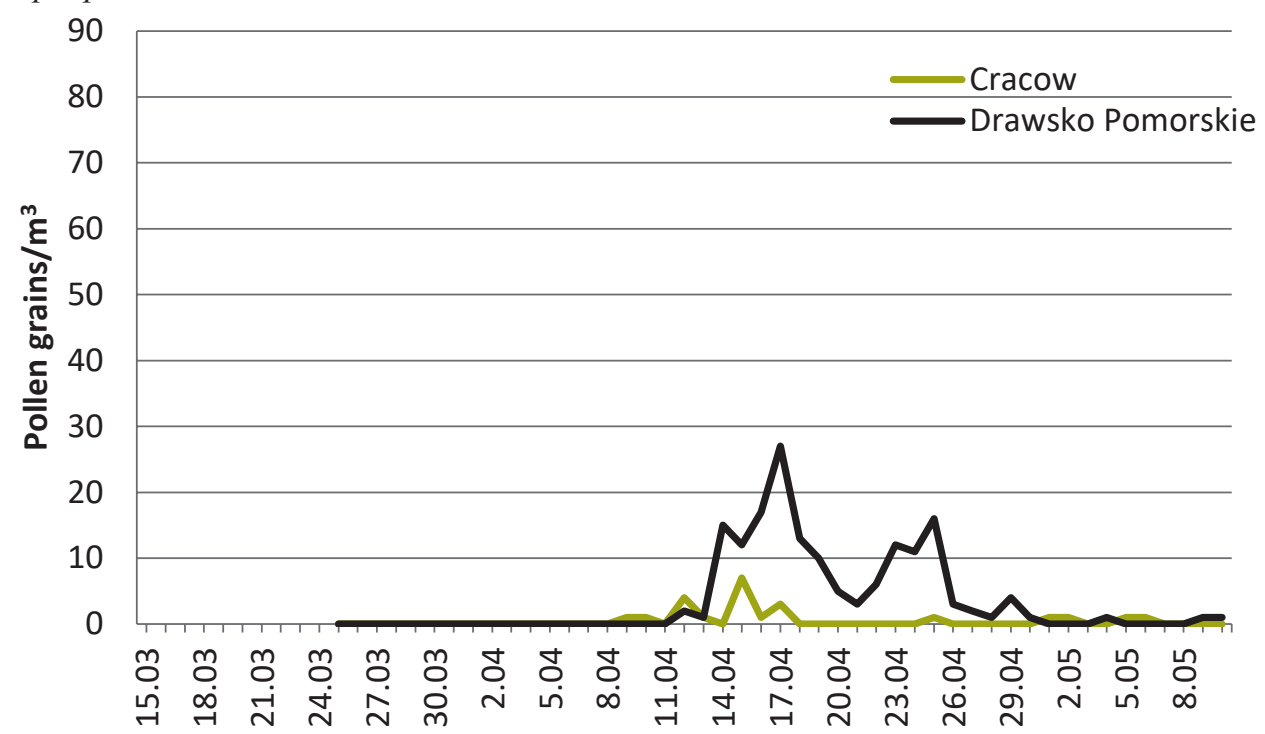


Figure 4. Maple pollen count in Warsaw and Zielona Gora in 2018.

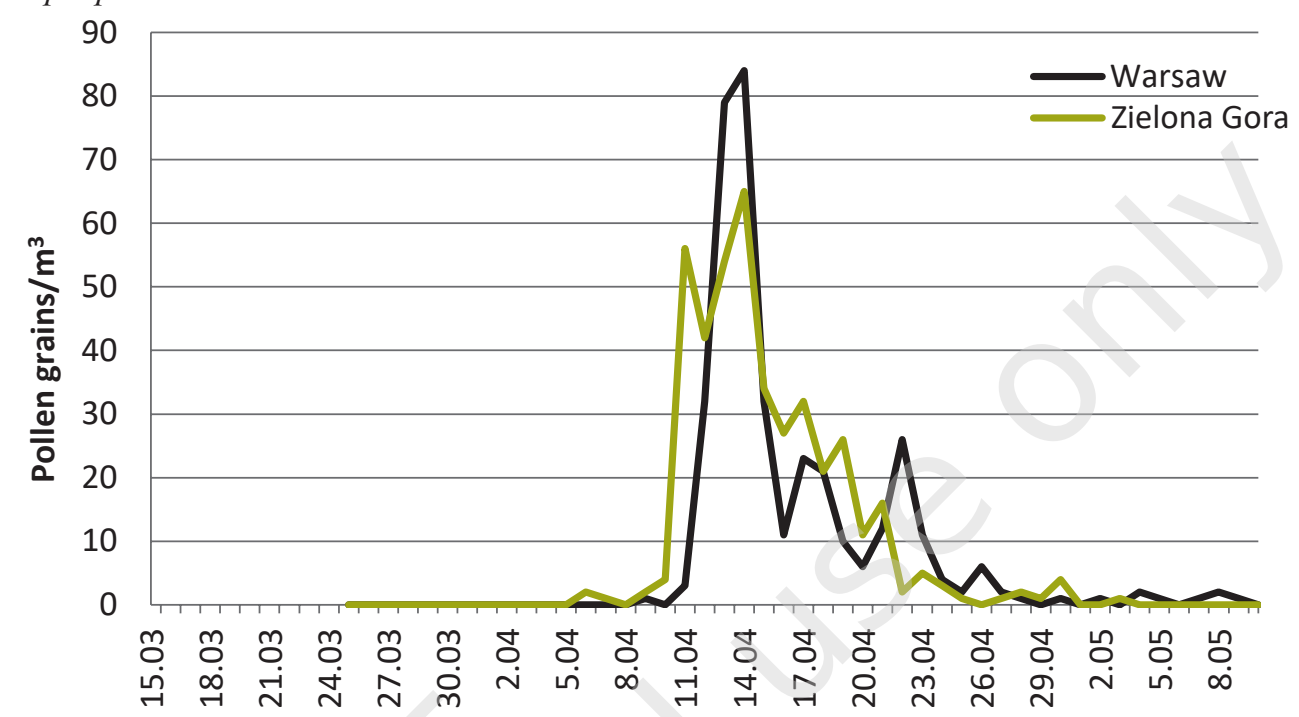

Figure 5. Maple pollen count in Piotrkow Trybunalski and Szczecin in 2018.

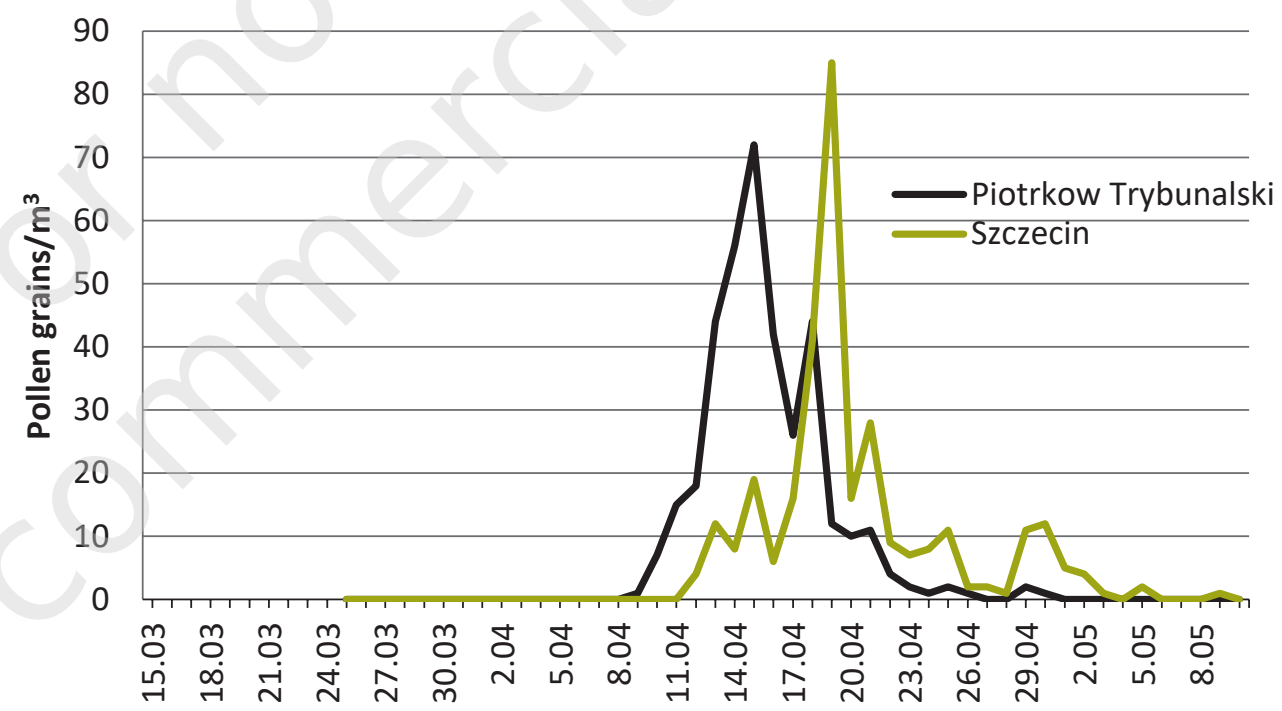

Figure 6. Maple pollen count in Bialystok and Bydgoszcz in 2018.

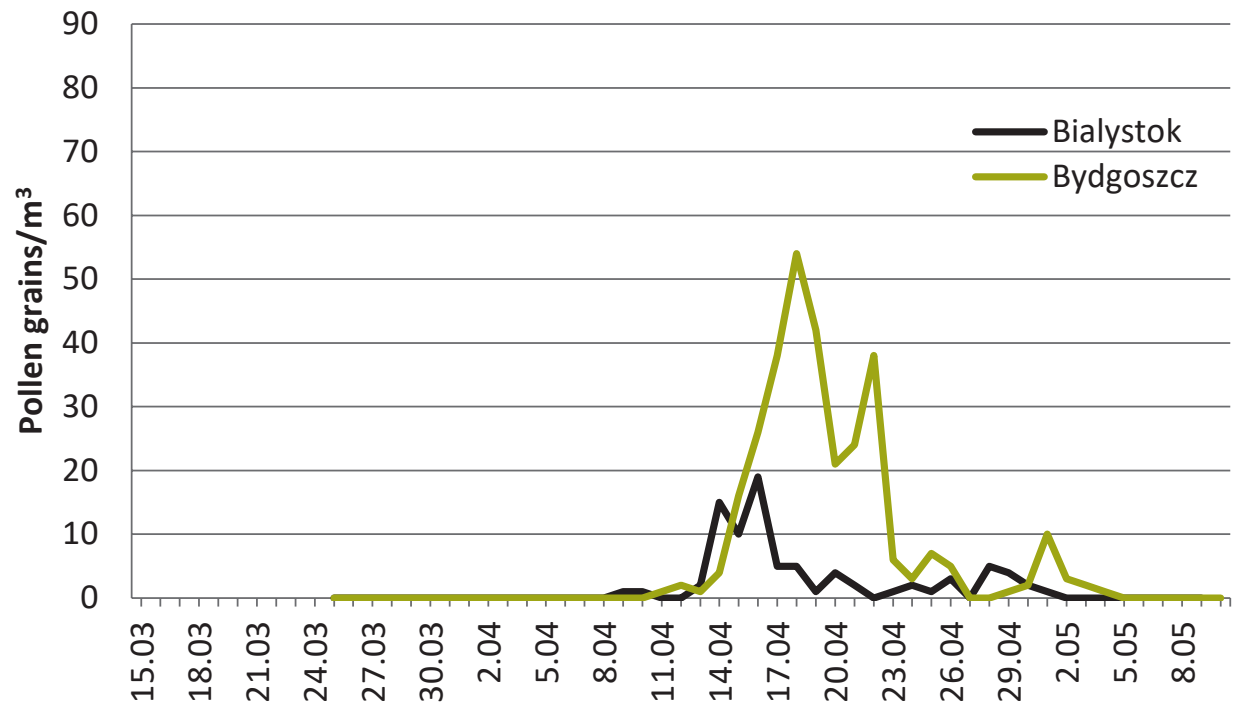


In 2018, the sums of maple pollen grains were in the range of 23-849; the highest sums of grains were noted in Sosnowiec (849), Lublin (701) and Opole (689) and the lowest total was recorded in Cracow (23) (tab. 1).

The allergy threat from maple pollen was low in 2018. The concentrations of pollen grains rarely exceeded the threshold values (above 20 and $50 \mathrm{P} / \mathrm{m}^{3}$ ), at which allergic reactions occur [10]. The greatest number of days with high pollen concentrations was recorded in Sosnowiec, Lublin, Opole and Zielona Gora while Cracow, Bialystok and Drawsko Pomorskie were characterised by the lowest number (tab. 1).

\section{Conclusions}

1. In 2018, the maple pollen season in all the analysed cities began in first decade of April, with the exception of Sosnowiec, where the season began already on March $16^{\text {th }}$.

2. The highest concentrations of maple pollen were recorded in Sosnowiec and Lublin, whereas the lowest concentrations were noted for Cracow.

3. The peak values of seasonal pollen count occurred between $12^{\text {th }}-20^{\text {th }}$ April in all cities.

4. The highest concentrations of $152 \mathrm{P} / \mathrm{m}^{3}$ was noted in Sosnowiec, and the lowest of $7 \mathrm{P} / \mathrm{m}^{3}$ in Cracow.

5. The greatest number of days with pollen concentrations exceeding the threshold value was recorded in Sosnowiec, Lublin and Opole.

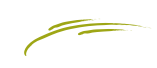

\section{References}

1. van Gelderen DM, de Jong PC, Oterdoom HJ. Maple of the World. Timber Press, Portland, Oregon 1994: 458.

2. de Jong PC. World Maple Diversity. International Maple Symposium. Gloucestershire, England, Westonbirt Arboretum and Royal Agricultural College, 2004.
3. Szweykowska A, Szweykowski J (red). Stownik botaniczny, Państwowe Wydawnictwo Wiedza Powszechna, Warszawa 2003.

4. Dajdok Z, Pawlaczyk P. Inwazyjne gatunki roślin ekosystemów mokradtowych Polski. Wydawnictwo Klubu Przyrodników, Świebodzin 2009

5. de Jong PC. Taxonomy and reproductive biology of maples. W: van Gelderen DM, de Jong PC, Oterdoom HJ (red). Maples of the World. Timber Press, Portland, USA 1991: 69-104.

6. Weryszko-Chmielewska E (red). Aerobiologia. Wydawnictwo Akademii Rolniczej, Lublin 2007.

7. Weryszko-Chmielewska E, Piotrowska-Weryszko K, Haratym $W$ et al. Changes in the pollen seasons of Acer spp. in Lublin, central-eastern Poland, in 2001-2015. Acta Agrobot 2016, 69(2): 1670 .

8. Spieksma FThM. 1991. Regional European Pollen Calendars. W: D'Amato G, Spieksma FThM, Bonini S (red). Allergenic pollen and pollinosis in Europe. Blackwell Sci Publ, London 1991: 49-65.

9. [online: www.polleninfo.org], accessed: 2018.06.15.

10. Rapiejko P. Medycyna a palinologia. W: Dybova-Jachowicz S, Sadowska A (red). Palinlogia. Instytut Botaniki PAN, Kraków 2002: 63-68.

\section{Author's contributions:}

Dąbrowska-Zapart K: 15\%; Chłopek K: 5\%; Świdnicka-Siergiejko A: 5\%; Siergiejko G: 5\%; Świebocka E: 5\%; Stacewicz A: 5\%; Ziemianin M: 5\%; Górecki A: 5\%; Piotrowska-Weryszko K: 5\%: Sulborska A: 5\%; Jurkiewicz D: 5\%; Kalinowska E: 5\%; Kwaśnik-Balińska A: 5\%; Szczygielski K: 5\%; Puc M: 5\%; Kotrych D: 5\%; Lipiec A: 5\%; Rapiejko P: $5 \%$. Conflict of interests: The authors declare that they have no competing interests.

Financial support: Does not occur.

Ethics: The contents presented in this paper are compatible with the rules the Declaration of Helsinki, EU directives and standardized requirements for medical journals.

Research in Bialystok, Bydgoszcz, Drawsko Pomorskie, Olsztyn, Opole, Piotrkow Trybunalski, Warsaw and Zielona Gora funded by Allergen Research Center Lto.

Corresponding author:

\section{Katarzyna Dąbrowska-Zapart, PhD}

Wydział Nauk o Ziemi, Uniwersytet Śląski

41-200 Sosnowiec, ul. Będzińska 60

tel. (+48 32) 368-94-77

e-mail: katarzyna.dabrowska-zapart@us.edu.pl 